\section{B A Institute of \\ YK Business Administration \\ 秉 \\ Karachi \\ Leadership and Ideas for Tomorrow}

Business Review

Volume 13 Issue 1 January-June 2018

6-12-2018

\title{
Can investors benefit from momentum trading? Evidence from an emerging market
}

\author{
Sana Tauseef \\ Institute of Business Administration, Karachi, Pakistan \\ Mohammad Nishat \\ Institute of Business Administration, Karachi, Pakistan
}

Follow this and additional works at: https://ir.iba.edu.pk/businessreview

Part of the Finance Commons

\section{(c) (1)}

This work is licensed under a Creative Commons Attribution 4.0 International License.

\section{Recommended Citation}

Tauseef, S., \& Nishat, M. (2018). Can investors benefit from momentum trading? Evidence from an emerging market. Business Review, 13(1), 21-36. Retrieved from https://doi.org/10.54784/ 1990-6587.1035

This article is brought to you by iRepository for open access under the Creative Commons Attribution 4.0 License and is available at https://ir.iba.edu.pk/businessreview/vol13/iss1/2. For more information, please contact irepository@iba.edu.pk. 


\title{
Can investors benefit from momentum trading? Evidence from an emerging market
}

\author{
Sana Tauseef . Mohammad Nishat
}

\begin{abstract}
It is claimed that momentum trading strategies generate positive returns. This paper investigates the profitability of momentum investment strategies and their determinants for stocks listed on the Pakistan Stock Exchange using data from the period 2001 to 2015. The results reveal that momentum returns for Pakistani stocks are as high as the returns reported for developed markets. Moreover, the returns earned over the sub-period 2001 to 2007 are mostly positive, whereas those earned over the sub-period 2009 to 2015 are mostly negative. Momentum returns in Pakistan, however, are not caused by temporary over or under reaction of investors in the market, neither can they be explained by the beta or size factor.
\end{abstract}

Keywords Momentum • Trading strategies · Pakistan Stock Exchange • Systematic risk factors.

\section{Introduction}

The efficient market hypothesis suggests that stock prices fully reflect all information available in the market and adjust very quickly to new information. Investors can therefore, not make arbitrage gains. However, there is vast literature that indicates the existence of market anomalies that allow investors to earn superior returns.

Over time, different factors have emerged that impact stock returns. Based on these factors, various asset pricing theories have been developed. One such factor, the price momentum, was first documented by (Jegadeesh and Titman 1993). Using the data for U.S. stocks for the period from 1965 to 1989, they

Sana Tauseef

Institute of Business Administration, University Road, Karachi-Pakistan

E-mail: sasghar@iba.edu.pk

Mohammad Nishat

Institute of Business Administration, University Road, Karachi-Pakistan 
found that trading strategies which involved buying good performing stocks and selling poor performing stocks generated positive returns over three to twelve month holding periods. However, these strategies did not provide positive returns in the very short-run (one month holding period) and in the long-run (one year or more) holding periods. Following Jegadeesh and Titman, a bulk of research documented the momentum effect in other developed markets (Rouwenhorst 1998; Gutierrez Jr and Kelley 2008).

Studies have also been conducted to investigate momentum effects in various emerging markets. However, the results on momentum patterns in emerging markets are not conclusive. Some studies have reported significant momentum returns in emerging markets. For example, Rouwenhorst (1999) used a sample of 20 emerging markets and concluded that like the developed markets, the developing markets also exhibit momentum returns which accrue gradually over a period of up to one year. Similarly, Muga and Santamaria (2007) investigated the results of momentum based trading strategies in four Latin American markets (Argentina, Brazil, Chile and Mexico) over the period 1994 to 2005. Even though the study period included the years when the Latin American markets were facing severe financial disturbance and economic crisis, strong momentum effects were found. Moreover, as opposed to the findings in other studies from developing markets, momentum returns reported by Muga and Santmaria were slightly higher than the returns reported for developed markets. They relate the higher momentum profits for emerging markets to the differing features of these markets, for example, low turnover, short-sale constraint and low analyst coverage.

In a recent study, Hanauer and Linhart (2015) examined the momentum patterns along with size and value factors for 21 emerging and 24 developed markets. They also reported significant momentum premium for all markets. Macha (2013) reported very strong momentum returns for stocks in the Shanghai stock market even after adjusting for market return and transaction costs. Misra and Mohapatra (2014) provided evidence of momentum in Indian stocks which according to them is an inherent factor in asset pricing.

On the contrary, there are studies that claim that momentum returns do not exist in emerging markets. Fernandes and Ornelas (2008) used a sample of fifteen emerging countries including Pakistan. They found negative momentum returns in both the short term and long term for most of the emerging markets.

Factors driving momentum patterns also remain a puzzle in financial literature. One set of studies argues that the profitability of momentum strategies has a rational source, and can be explained by the missing risk factors. These studies have related momentum profits to firms' characteristics like size and book-tomarket ratio (Conrad and Kaul 1998), earnings momentum (Chan et al 1996), sector momentum (Moskowitz and Grinblatt 1999), and the macroeconomic conditions (Chordia and Shivakumar 2002). The other set of studies explains momentum patterns on the basis of behavioral factors, suggesting that overreaction (Daniel et al 1998) or under-reaction bias (Barberis et al 1998) results in price persistence.

This study re-examines the existence of momentum patterns and explores the determinants of momentum using data from the Pakistan Stock Exchange 
(PSX). The study was motivated by four factors. First, most of the studies on price momentum have reported the findings from developed markets and the evidence from emerging markets remains limited. Second, the two studies available on the topic using Pakistani stocks data (Habib-Ur-Rahman and Mohsin 2012; Shah and Shah 2015) have reported contradictory findings. Habib-Ur-Rahman and Mohsin (2012) concluded that a weak momentum effect exists for the listed stocks in Pakistan. Their study evaluated sixteen momentum strategies as used by Jegadeesh and Titman (1993) and reported positive return for only one strategy where the formation period was twelve months and the holding period was nine months. ${ }^{1}$ All other short-term momentum strategies earned a negative return and the losses followed a decreasing trend as the holding period increased. On the contrary, Shah and Shah (2015) reported strong momentum returns for Pakistani stocks. They constructed momentum strategies with equal formation and holding periods, from 1 month to 24 months and found positive profits for most of the strategies. The highest return was reported in the short-term when the formation and holding period was two and three months and the momentum profits decreased as the length of the formation and holding period increased. ${ }^{2}$ Such contradictory findings from a single market can be attributed to the different study periods and methodology used by the two studies. Habib-Ur-Rahman and Mohsin (2012) used the data for the period January 1999 to December 2007 and constructed portfolios with full rebalancing, whereas Shah and Shah (2015) used a sample from the period June 2004 to March 2014 and followed partial rebalancing. ${ }^{3}$ Given the entirely opposite results from the same market, there was an utmost need to cross-check the findings with an extended and more recent period.

Thirdly, literature suggests that there can be a significant momentum effect in the industry component of stock (Moskowitz and Grinblatt 1999) and momentum profits are dependent on the market state (Cooper et al 2004). None of the previous studies conducted using Pakistani stock data have investigated whether momentum patterns are different for different industries or for periods experiencing different economic and financial market conditions. Our study tests momentum profits separately for two sectors, financial and non-financial, and for two sub-periods, 2001 to 2007 and 2009 to 2015, to check for the robustness of the results obtained for the entire sample and complete period.

Finally, the decision to upgrade Pakistan Stock Exchange from the frontier to emerging markets by MSCI in June 2016 has made Pakistan's financial market more attractive to local and foreign investors. By providing knowledge regarding persistence of stock prices and the different risk factors causing it, the study aims to enable the investors to make more reliable and informed investment decisions.

\footnotetext{
1 Habib-Ur-Rahman and Mohsin (2012) reported an average monthly return of 1.25 percent for the strategy with the formation period of twelve months and holding period of nine months.

2 Shah and Shah (2015) reported an annual return of 15.42 percent for the strategy with the formation and holding periods of two months when all stocks in the sample were used.

${ }^{3}$ In full rebalancing, the portfolios are constructed at the end of each formation period, whereas in partial rebalancing portfolios are constructed at the end of each month resulting in overlapping holding periods.
}

Business Review: (2018) 13(1):21-36 


\section{Study sample and methodology}

Our sample included all firms listed on the PSX over the period from January 2000 to December 2015. The selected sample period was the post-reform period when the financial system of Pakistan including the equity market was strong and diversified. ${ }^{4}$ The sample period is also justified based on the availability of financial data.

We excluded firms with missing data, firms which were infrequently traded, and firms with negative book equity. Infrequently traded firms (firms with zero returns for a continuous six-month period) were excluded as the shares of such firms could not be traded in time as per the requirement of the investment strategy. Firms with negative book equity were excluded as they are financially distressed firms with a high default risk and are not comparable with normal firms. Our final sample consisted of 180 firms out of which 46 were from the financial sector and 134 were non-financial firms.

We calculated the momentum profits following the methodology used by Jegadeesh and Titman (1993) in their seminal work. We selected the stocks based on the returns over the past 3, 6, 9, 12 and 24 month period and held the stocks for the following 3, 6, 9, 12 and 24 months. A total of 25 strategies were, thus, considered combining the selection period and the holding period. ${ }^{5}$ Each month, stocks were ranked in ascending order of their average monthly return. Stocks were then classified into ten portfolios (deciles) based on the above ranking. Thus, the first portfolio (loser) contained ten percent stocks with the lowest average monthly prior returns and the last portfolio (winner) contained ten percent stocks with the highest average monthly prior returns. Momentum strategy involves buying the winner portfolio and selling the loser portfolio and holding these portfolios for their respective holding periods.

The portfolios were examined recursively. For example, for the 3-3 strategy in the sixth month, there were portfolios selected in the fourth, fifth and sixth month and so on. To avoid microstructure biases, two versions of the portfolios were formed, first one immediately following the period used for stock ranking and the other one with a lag of one month between the portfolio formation and the holding period.

\section{Results and discussion}

Table 1 reports the average monthly returns of the buy (winners), sell (losers) and momentum (buy minus sell) portfolios for the 25 strategies (with formation and holding periods of 3, 6, 9, 12 and 24 months) when there is no lag between the formation period and the holding period. Twenty out of the total twenty five strategies presented in the table earned positive returns with eight of these twenty strategies reporting a momentum return greater than one percent per

\footnotetext{
4 The financial system of Pakistan underwent a series of deregulation and liberalization policies in early 1990's. These reforms included permitting the foreign investors to buy the shares of listed firms, establishment of a public debt system and an efficient monetary policy with less government interference.

5 The twenty-five momentum strategies are listed in appendix A.
} 
month.

The highest momentum profit reported, on average, is 1.80 percent (23.4 percent on annualized basis) and was earned by the strategy with a formation period of twelve months and a holding period of six months. The return reported for the most profitable strategy is higher than the return of the most profitable strategy as reported in many studies, however, the returns earned by these strategies are not statistically significant. ${ }^{6}$

The lowest momentum return was earned for the very short-term strategy (33 strategy) which is consistent with previous literature; however, for our study, this strategy has earned negative momentum return. ${ }^{7}$ When the momentum returns were calculated with a one-month lag between the formation period and the holding period (as presented in table 2), 9-3 strategy yielded the highest profit and there were few momentum strategies earning significant returns.

\subsection{Momentum returns for financial and non-financial firms}

Since our sample consisted of both financial and non-financial firms, we checked the validity of our findings for the sub-samples of financial and non-financial firms. The momentum returns for the sub-samples were computed over the complete period and are presented in table 3 for non-financial firms and in table 4 for the financial firms. Due to the small number of financial firms, the momentum returns were calculated using quintile portfolios instead of decile portfolios.

The results found for the sub-sample of non-financial and financial firms were similar to the results for the overall sample with most of the strategies yielding positive but insignificant momentum returns. The highest momentum return for the sample of non-financial firms (1.63 percent per month reported for 9-6 strategy) was lesser as compared to the highest momentum return for the sample of financial firms (1.94 percent per month reported for 6-6 strategy). Slightly higher returns for financial firms might be the result of high leverage employed by these firms which amplifies the returns, hence widening the difference between the returns of high performers and low performers.

\subsection{Performance of momentum portfolios in sub-periods}

The insignificant results for all strategies based on the total sample as well as the subsamples of financial and non-financial firms confirm the existence of a weak momentum effect in Pakistan's equity market, a finding previously reported by (Habib-Ur-Rahman and Mohsin 2012). To check for the robustness of this finding, we examined the performance of momentum portfolios for the two sub-periods: 2001 till 2007 and 2009 till 2015. The year 2008 was not included

\footnotetext{
6 Jegadeesh and Titman (1993) reported the highest monthly return of 1.49 percent for the strategy with a twelve-month formation period and a three-month holding period.

7 3-3 strategy earns -2 percent per month which is equal to an annualized return of -26.8 percent.
} 
in the analysis as this year experienced a market crash with sharp decline in stock prices for some months and the imposition of a floor rule resulting in a near paralysis of the equities market for more than three months.

The investigation of the momentum returns in the two sub-periods is highly crucial as the two sub-periods experienced different political regimes and macroeconomic fundamentals. The first sub-period was the pre-crisis period when there was an autocratic government, high economic growth, low inflation and better governance (Haider et al 2011). ${ }^{8}$ The second sub-period was the post-crisis period characterized by a democratic government, low economic growth and high inflation.

Momentum returns for the two sub-periods, 2001-2007 and 2009-2015, are presented in table 5 and table 6 , respectively. A comparison of these returns shows that the two periods had completely contrasting momentum effects. There was a strong positive momentum effect in the first sub-period with 22 out of 25 strategies earning a momentum return of more than one percent per month. The most successful strategy was 12-6 which earned a return of 5.37 percent per month.

As opposed to this, the momentum returns were negative for 24 out of 25 strategies in the second sub-period. Even the 12-6 strategy which yielded the highest return over the complete sample period earned a negative return $(-0.10$ percent per month) over the second sub-period. The 6-3 strategy yielded the lowest return (-2 percent per month). The contrasting results for the two subperiods show that along with the macroeconomic fundamentals like GDP growth rate and inflation, the outcomes of the investment strategies in Pakistan have also been influenced by political regimes (autocratic versus democratic). The profitable momentum investment strategies during the autocratic regime yielded negative returns during the democratic regimes. These differing results for the sub-periods can also be attributed to the change in market dynamics due to the crisis.

We then examined the factors causing the momentum patterns using two momentum strategies: $12-6$ and $6-6$ strategies. The first strategy is the most profitable strategy as found by this study and the second strategy is the most popular strategy used in literature..$^{9}$

\subsection{Performance of momentum portfolios in event time}

This section examines the returns on momentum portfolios for a 36-month period following the formation period. Momentum returns after the holding period indicate whether they are the result of irrational investor behavior (over or under reaction) or some other systematic factors. If the positive returns during the holding period reverse and are followed by negative returns, it implies that the

\footnotetext{
8 Autocratic regimes in Pakistan have experienced high economic growth, low inflation and better governance as compared to democratic regimes. See Adnan et al. (2011) for comprehensive comparison of macroeconomic indicators during the different political regimes in Pakistan.

9 Most of the studies in literature, for example, Jegadeesh and Titman (1993) and Rouwenhorst (1998), used the 6-6 strategy for further investigation of momentum patterns.
} 
Can investors benefit from momentum trading...

\begin{tabular}{|c|c|c|c|c|c|c|c|}
\hline $\mathrm{J}$ & & $\mathrm{K}=$ & 3 & 6 & 9 & 12 & 24 \\
\hline 3 & Sell & & 0.061 & 0.054 & 0.049 & 0.047 & 0.045 \\
\hline 3 & Buy & & 0.041 & 0.047 & 0.049 & 0.049 & 0.046 \\
\hline 3 & Buy-Sell & & $\begin{array}{c}-0.020 \\
(-1.634)\end{array}$ & $\begin{array}{l}-0.007 \\
(-1.273)\end{array}$ & $\begin{array}{c}0.000 \\
(-0.024)\end{array}$ & $\begin{array}{c}0.002 \\
(0.389)\end{array}$ & $\begin{array}{c}0.001 \\
(0.271)\end{array}$ \\
\hline 6 & Sell & & 0.054 & 0.046 & 0.046 & 0.045 & 0.046 \\
\hline 6 & Buy & & 0.047 & 0.055 & 0.056 & 0.055 & 0.052 \\
\hline 6 & Buy-Sell & & $\begin{array}{c}-0.007 \\
(-0.496)\end{array}$ & $\begin{array}{c}0.009 \\
(0.698)\end{array}$ & $\begin{array}{c}0.011 \\
(1.005)\end{array}$ & $\begin{array}{c}0.010 \\
(1.176)\end{array}$ & $\begin{array}{c}0.006 \\
(0.805)\end{array}$ \\
\hline 9 & Sell & & 0.048 & 0.043 & 0.043 & 0.043 & 0.043 \\
\hline 9 & Buy & & 0.050 & 0.055 & 0.055 & 0.052 & 0.051 \\
\hline 9 & Buy-Sell & & $\begin{array}{c}0.002 \\
(0.134)\end{array}$ & $\begin{array}{c}0.012 \\
(0.936)\end{array}$ & $\begin{array}{c}0.012 \\
(0.963)\end{array}$ & $\begin{array}{c}0.009 \\
(0.871)\end{array}$ & $\begin{array}{c}0.008 \\
(0.801)\end{array}$ \\
\hline 12 & Sell & & 0.045 & 0.044 & 0.043 & 0.044 & 0.041 \\
\hline 12 & Buy & & 0.058 & 0.061 & 0.058 & 0.055 & 0.054 \\
\hline 12 & Buy-Sell & & $\begin{array}{c}0.013 \\
(0.843)\end{array}$ & $\begin{array}{c}0.018 \\
(1.071)\end{array}$ & $\begin{array}{c}0.015 \\
(1.002)\end{array}$ & $\begin{array}{c}0.011 \\
(0.847)\end{array}$ & $\begin{array}{c}0.012 \\
(1.002)\end{array}$ \\
\hline 24 & Sell & & 0.040 & 0.038 & 0.036 & 0.035 & 0.034 \\
\hline 24 & Buy & & 0.037 & 0.039 & 0.040 & 0.041 & 0.042 \\
\hline 24 & Buy-Sell & & $\begin{array}{c}-0.003 \\
(-0.255)\end{array}$ & $\begin{array}{c}0.002 \\
(0.148)\end{array}$ & $\begin{array}{c}0.004 \\
(0.346)\end{array}$ & $\begin{array}{c}0.006 \\
(0.493)\end{array}$ & $\begin{array}{c}0.008 \\
(0.750)\end{array}$ \\
\hline
\end{tabular}

Note: t-statistics are given in parentheses. ${ }^{*}$ and $* *$ denote statistical significance at 10 percent and 5 percent levels, respectively.

Table 2: Returns for momentum portfolios over the period 2001-2015 with 1month lag period

\begin{tabular}{|c|c|c|c|c|c|c|c|}
\hline $\mathrm{J}$ & & $K=$ & 3 & 6 & 9 & 12 & 24 \\
\hline 3 & Sell & & 0.044 & 0.044 & 0.043 & 0.041 & 0.042 \\
\hline 3 & Buy & & 0.050 & 0.051 & 0.051 & 0.051 & 0.047 \\
\hline \multirow[t]{2}{*}{3} & Buy-Sell & & 0.006 & 0.007 & 0.008 & 0.010 & 0.005 \\
\hline & & & $(0.923)$ & $(0.907)$ & $(1.396)$ & $\left(1.683^{*}\right)$ & (1.134) \\
\hline 6 & Sell & & 0.041 & 0.042 & 0.042 & 0.041 & 0.042 \\
\hline 6 & Buy & & 0.055 & 0.059 & 0.056 & 0.056 & 0.053 \\
\hline \multirow[t]{2}{*}{6} & Buy-Sell & & 0.014 & 0.017 & 0.015 & 0.015 & 0.011 \\
\hline & & & $(1.061)$ & $(1.382)$ & $(1.548)$ & $\left(1.713^{*}\right)$ & $(1.421)$ \\
\hline 9 & Sell & & 0.042 & 0.039 & 0.039 & 0.039 & 0.039 \\
\hline 9 & Buy & & 0.090 & 0.057 & 0.056 & 0.054 & 0.053 \\
\hline \multirow[t]{2}{*}{9} & Buy-Sell & & 0.048 & 0.018 & 0.017 & 0.015 & 0.014 \\
\hline & & & $\left(1.791^{*}\right)$ & $(1.472)$ & $(1.540)$ & $(1.402)$ & $(1.367)$ \\
\hline 12 & Sell & & 0.036 & 0.037 & 0.037 & 0.038 & 0.035 \\
\hline 12 & Buy & & 0.066 & 0.063 & 0.059 & 0.057 & 0.055 \\
\hline \multirow[t]{2}{*}{12} & Buy-Sell & & 0.030 & 0.026 & 0.022 & 0.019 & 0.021 \\
\hline & & & $\left(1.852^{*}\right)$ & $\left(1.658^{*}\right)$ & (1.643) & $(1.483)$ & $\left(1.775^{*}\right)$ \\
\hline 24 & Sell & & 0.035 & 0.035 & 0.034 & 0.034 & 0.033 \\
\hline 24 & Buy & & 0.039 & 0.040 & 0.041 & 0.041 & 0.042 \\
\hline \multirow[t]{2}{*}{24} & Buy-Sell & & 0.004 & 0.005 & 0.007 & 0.007 & 0.010 \\
\hline & & & $(0.321)$ & $(0.451)$ & $(0.601)$ & $(0.591)$ & $(0.900)$ \\
\hline
\end{tabular}

Note: t-statistics are given in parentheses. $*$ and $* *$ denote statistical significance at 10 percent and 5 percent levels, respectively. 
S. Tauseef, M. Nishat

Table 3: Returns for momentum portfolios of non-financial firms

\begin{tabular}{|c|c|c|c|c|c|c|c|}
\hline $\mathrm{J}$ & & $\mathrm{K}=$ & 3 & 6 & 9 & 12 & 24 \\
\hline 3 & Sell & & 0.059 & 6.288 & 0.051 & 0.047 & 0.044 \\
\hline 3 & Buy & & 0.047 & 0.047 & 0.053 & 0.052 & 0.049 \\
\hline \multirow[t]{2}{*}{3} & Buy-Sell & & -0.012 & -0.008 & 0.002 & 0.005 & 0.005 \\
\hline & & & $(-0.872)$ & $(-1.362)$ & $(0.218)$ & $(0.741)$ & $(0.807)$ \\
\hline 6 & Sell & & 0.056 & 0.050 & 0.047 & 0.046 & 0.045 \\
\hline 6 & Buy & & 0.052 & 0.059 & 0.058 & 0.055 & 0.054 \\
\hline \multirow[t]{2}{*}{6} & Buy-Sell & & -0.005 & 0.009 & 0.011 & 0.009 & 0.009 \\
\hline & & & $(-0.264)$ & $(0.611)$ & $(0.920)$ & $(1.048)$ & (1.037) \\
\hline 9 & Sell & & 0.052 & 0.046 & 0.045 & 0.044 & 0.042 \\
\hline 9 & Buy & & 0.054 & 0.062 & 0.061 & 0.059 & 0.059 \\
\hline \multirow[t]{2}{*}{9} & Buy-Sell & & 0.003 & 0.016 & 0.016 & 0.014 & 0.017 \\
\hline & & & $(0.146)$ & (1.038) & (1.132) & (1.153) & (1.334) \\
\hline 12 & Sell & & 0.048 & 0.048 & 0.047 & 0.046 & 0.043 \\
\hline 12 & Buy & & 0.060 & 0.060 & 0.058 & 0.057 & 0.057 \\
\hline \multirow[t]{2}{*}{12} & Buy-Sell & & 0.012 & 0.012 & 0.012 & 0.010 & 0.015 \\
\hline & & & $(0.688)$ & $(0.680)$ & $(0.703)$ & $(0.651)$ & $(0.936)$ \\
\hline 24 & Sell & & 0.043 & 0.041 & 0.038 & 0.037 & 0.036 \\
\hline 24 & Buy & & 0.039 & 0.042 & 0.043 & 0.043 & 0.044 \\
\hline \multirow[t]{2}{*}{24} & Buy-Sell & & -0.004 & 0.001 & 0.004 & 0.006 & 0.009 \\
\hline & & & $(-0.264)$ & $(0.087)$ & $(0.311)$ & $(0.414)$ & $(0.638)$ \\
\hline
\end{tabular}

Note: t-statistics are given in parentheses. ${ }^{*}$ and $* *$ denote statistical significance at 10 percent and 5 percent levels, respectively.

Table 4: Returns for momentum portfolios of financial firms

\begin{tabular}{|c|c|c|c|c|c|c|c|}
\hline $\mathrm{J}$ & & $\mathrm{K}=$ & 3 & 6 & 9 & 12 & 24 \\
\hline 3 & Sell & & 0.048 & 0.038 & 0.036 & 0.037 & 0.039 \\
\hline 3 & Buy & & 0.025 & 0.041 & 0.039 & 0.038 & 0.035 \\
\hline \multirow[t]{2}{*}{3} & Buy-Sell & & -0.022 & 0.003 & 0.002 & 0.002 & -0.004 \\
\hline & & & $\left(-2.276^{* *}\right)$ & $(0.286)$ & $(0.314)$ & $(0.272)$ & $(-1.045)$ \\
\hline 6 & Sell & & 0.036 & 0.031 & 0.034 & 0.034 & 0.038 \\
\hline 6 & Buy & & 0.053 & 0.051 & 0.047 & 0.048 & 0.041 \\
\hline \multirow[t]{2}{*}{6} & Buy-Sell & & 0.017 & 0.019 & 0.013 & 0.014 & 0.002 \\
\hline & & & $(0.660)$ & $(0.870)$ & $(0.820)$ & $(0.794)$ & $(0.304)$ \\
\hline 9 & Sell & & 0.055 & 0.031 & 0.032 & 0.033 & 0.038 \\
\hline 9 & Buy & & 0.059 & 0.039 & 0.039 & 0.037 & 0.035 \\
\hline \multirow[t]{2}{*}{9} & Buy-Sell & & 0.005 & 0.008 & 0.008 & 0.004 & -0.003 \\
\hline & & & $(0.199)$ & $(0.641)$ & $(0.618)$ & $(0.389)$ & $(-0.500)$ \\
\hline 12 & Sell & & 0.034 & 0.030 & 0.032 & 0.032 & 0.033 \\
\hline 12 & Buy & & 0.041 & 0.047 & 0.042 & 0.039 & 0.036 \\
\hline \multirow[t]{2}{*}{12} & Buy-Sell & & 0.007 & 0.017 & 0.010 & 0.007 & 0.003 \\
\hline & & & $(0.515)$ & $(0.859)$ & $(0.713)$ & $(0.586)$ & $(0.437)$ \\
\hline 24 & Sell & & 0.027 & 0.027 & 0.027 & 0.026 & 0.026 \\
\hline 24 & Buy & & 0.031 & 0.034 & 0.034 & 0.034 & 0.035 \\
\hline \multirow[t]{2}{*}{24} & Buy-Sell & & 0.004 & 0.008 & 0.007 & 0.008 & 0.010 \\
\hline & & & $(0.405)$ & $(0.722)$ & $(0.685)$ & $(0.801)$ & $(1.165)$ \\
\hline
\end{tabular}

Note: t-statistics are given in parentheses. $*$ and $* *$ denote statistical significance at 10 percent and 5 percent levels, respectively. 
Can investors benefit from momentum trading...

Table 5: Returns for momentum portfolios for the sub-period 2001-2007

\begin{tabular}{|c|c|c|c|c|c|c|c|}
\hline $\mathrm{J}$ & & $\mathrm{K}=$ & 3 & 6 & 9 & 12 & 24 \\
\hline 3 & Sell & & 0.081 & 0.070 & 0.062 & 0.060 & 0.059 \\
\hline 3 & Buy & & 0.055 & 0.067 & 0.072 & 0.072 & 0.070 \\
\hline 3 & Buy-Sell & & $\begin{array}{c}-0.026 \\
(-1.047)\end{array}$ & $\begin{array}{c}-0.003 \\
(-0.275)\end{array}$ & $\begin{array}{c}0.011 \\
(0.941)\end{array}$ & $\begin{array}{c}0.011 \\
(1.392)\end{array}$ & $\begin{array}{c}0.011 \\
(1.381)\end{array}$ \\
\hline 6 & Sell & & 0.069 & 0.056 & 0.057 & 0.058 & 0.059 \\
\hline 6 & Buy & & 0.073 & 0.090 & 0.092 & 0.090 & 0.085 \\
\hline 6 & Buy-Sell & & $\begin{array}{c}0.004 \\
(0.122)\end{array}$ & $\begin{array}{c}0.034 \\
(1.323)\end{array}$ & $\begin{array}{c}0.035 \\
(1.619)\end{array}$ & $\begin{array}{c}0.031 \\
\left(1.897^{*}\right)\end{array}$ & $\begin{array}{c}0.026 \\
\left(1.671^{*}\right)\end{array}$ \\
\hline 9 & Sell & & 0.061 & 0.050 & 0.053 & 0.054 & 0.058 \\
\hline 9 & Buy & & 0.082 & 0.093 & 0.092 & 0.054 & 0.086 \\
\hline 9 & Buy-Sell & & $\begin{array}{c}0.021 \\
(0.723)\end{array}$ & $\begin{array}{c}0.043 \\
(1.549)\end{array}$ & $\begin{array}{c}0.039 \\
(1.544)\end{array}$ & $\begin{array}{c}0.034 \\
(1.556)\end{array}$ & $\begin{array}{c}0.028 \\
(1.263)\end{array}$ \\
\hline 12 & Sell & & 0.057 & 0.056 & 0.055 & 0.053 & 0.061 \\
\hline 12 & Buy & & 0.101 & 0.109 & 0.102 & 0.097 & 0.092 \\
\hline 12 & Buy-Sell & & $\begin{array}{c}0.044 \\
(1.394)\end{array}$ & $\begin{array}{c}0.054 \\
(1.497)\end{array}$ & $\begin{array}{c}0.048 \\
(1.505)\end{array}$ & $\begin{array}{c}0.044 \\
(1.512)\end{array}$ & $\begin{array}{c}0.032 \\
(1.159)\end{array}$ \\
\hline 24 & Sell & & 0.049 & 0.046 & 0.043 & 0.043 & 0.043 \\
\hline 24 & Buy & & 0.069 & 0.071 & 0.071 & 0.070 & 0.073 \\
\hline 24 & Buy-Sell & & $\begin{array}{c}0.020 \\
(0.714)\end{array}$ & $\begin{array}{c}0.025 \\
(0.963)\end{array}$ & $\begin{array}{c}0.028 \\
(1.080)\end{array}$ & $\begin{array}{c}0.027 \\
(1.040)\end{array}$ & $\begin{array}{c}0.030 \\
(1.165)\end{array}$ \\
\hline
\end{tabular}

Note: t-statistics are given in parentheses. $*$ and $* *$ denote statistical significance at 10 percent and 5 percent levels, respectively.

Table 6: Returns for momentum portfolios for the sub-period 2009-2015

\begin{tabular}{|c|c|c|c|c|c|c|c|}
\hline $\mathrm{J}$ & & $\mathrm{K}=$ & 3 & 6 & 9 & 12 & 24 \\
\hline 3 & Sell & & 0.054 & 0.049 & 0.049 & 0.046 & 0.045 \\
\hline 3 & Buy & & 0.039 & 0.039 & 0.040 & 0.041 & 0.037 \\
\hline 3 & Buy-Sell & & $\begin{array}{c}-0.014 \\
(-1.565)\end{array}$ & $\begin{array}{l}-0.010 \\
(-1.479)\end{array}$ & $\begin{array}{l}-0.009 \\
(-1.468)\end{array}$ & $\begin{array}{c}-0.006 \\
(-0.982)\end{array}$ & $\begin{array}{l}-0.008 \\
(-1.481)\end{array}$ \\
\hline 6 & Sell & & 0.055 & 0.051 & 0.050 & 0.049 & 0.051 \\
\hline 6 & Buy & & 0.034 & 0.037 & 0.039 & 0.039 & 0.035 \\
\hline 6 & Buy-Sell & & $\begin{array}{c}-0.020 \\
\left(-2.120^{* *}\right)\end{array}$ & $\begin{array}{c}-0.014 \\
(-1.556)\end{array}$ & $\begin{array}{c}-0.011 \\
(-1.289)\end{array}$ & $\begin{array}{c}-0.010 \\
(-1.256)\end{array}$ & $\begin{array}{c}-0.016 \\
\left(-2.138^{* *}\right)\end{array}$ \\
\hline 9 & Sell & & 0.046 & 0.044 & 0.043 & 0.042 & 0.040 \\
\hline 9 & Buy & & 0.036 & 0.037 & 0.037 & 0.035 & 0.034 \\
\hline 9 & Buy-Sell & & $\begin{array}{c}-0.010 \\
(-1.041)\end{array}$ & $\begin{array}{c}-0.007 \\
(-0.810)\end{array}$ & $\begin{array}{c}-0.006 \\
(-0.748)\end{array}$ & $\begin{array}{c}-0.007 \\
(-0.882)\end{array}$ & $\begin{array}{c}-0.007 \\
(-1.000)\end{array}$ \\
\hline 12 & Sell & & 0.042 & 0.038 & 0.038 & 0.039 & 0.035 \\
\hline 12 & Buy & & 0.038 & 0.038 & 0.037 & 0.035 & 0.036 \\
\hline 12 & Buy-Sell & & $\begin{array}{l}-0.004 \\
(-0.410)\end{array}$ & $\begin{array}{l}-0.001 \\
(-0.058)\end{array}$ & $\begin{array}{l}-0.001 \\
(-0.085)\end{array}$ & $\begin{array}{c}-0.004 \\
(-0.433)\end{array}$ & $\begin{array}{c}0.001 \\
(0.168)\end{array}$ \\
\hline 24 & Sell & & 0.044 & 0.040 & 0.043 & 0.040 & 0.039 \\
\hline 24 & Buy & & 0.030 & 0.033 & 0.034 & 0.036 & 0.038 \\
\hline 24 & Buy-Sell & & $\begin{array}{c}-0.014 \\
(-1.171)\end{array}$ & $\begin{array}{l}-0.008 \\
(-0.729)\end{array}$ & $\begin{array}{l}-0.008 \\
(-0.818)\end{array}$ & $\begin{array}{c}-0.005 \\
(-0.463)\end{array}$ & $\begin{array}{l}-0.001 \\
(-0.109)\end{array}$ \\
\hline
\end{tabular}

Note: t-statistics are given in parentheses. $*$ and $* *$ denote statistical significance at 10 percent and 5 percent levels, respectively. 
momentum returns are temporary and are caused by over or under reaction of the investors. However, if the positive returns continue after the holding period, it implies that the returns are caused by some rational risk factors (Jegadeesh and Titman 1993).

Monthly momentum returns (up to 36 months) and cumulative returns for
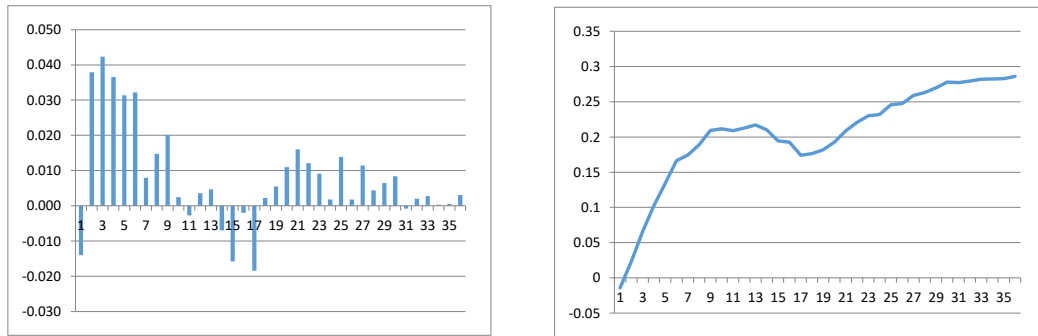

Fig 1: Monthly and cumulative event returns for 12-month formation period

the momentum portfolio formed on 12-month prior returns are presented in table 7 . The portfolio cumulated a return of 16.60 percent in six months. There were some negative returns in the post-holding period window (figure 1); however, the positive returns continued for most months and the cumulative returns (figure 1) increased over the event period. The portfolio earned a cumulative return of 21.20 percent in twelve months and a cumulative return of 28.60 percent in 36 months.

Table 8 presents the average monthly momentum returns (up to 36 months)
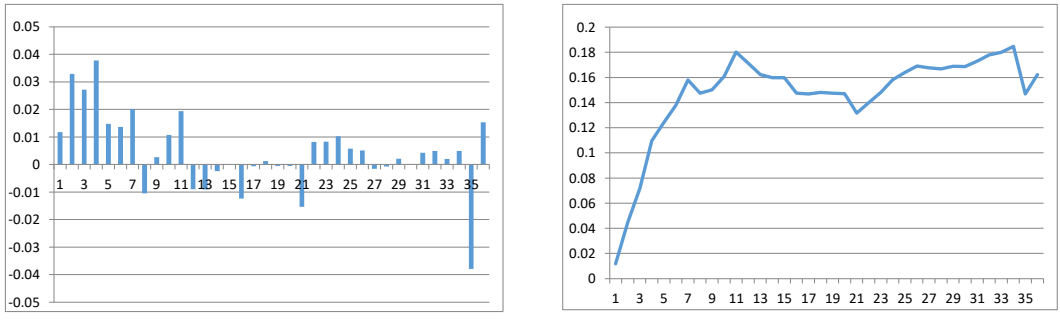

Fig 2: Monthly and cumulative event returns for 6-month formation period

and average cumulative returns for the momentum portfolios formed on 6 -month prior returns. These portfolios, on average, cumulated a return of 13.80 percent in 6 months. In the post-holding period, there were many months with negative returns (figure 2) and the cumulative returns (figure 2) did not increase as sharply as for the 12-month formation strategy. The portfolios, on average, earned a cumulative return of 17.10 percent in 12 months and a cumulative return of 16.20 percent in 36 months. The observed trend in the event period returns suggests that the returns are not temporary and hence can be explained by some rational risk factors. 


\subsection{Systematic factors and momentum returns}

Finally, we checked for the possibility of a relationship between momentum returns and the systematic risk factors of beta and size. If the outperforming stocks carry higher market risk or they are small in size, then their higher returns are justified by their high risk factors and momentum returns will disappear once the stock selection incorporates the size and beta factors. However, if momentum returns are not related to the systematic factors, then this represents an additional factor explaining the variation in stock returns (Fama and French 1992; Jegadeesh and Titman 1993).

Table 7: Event returns for momentum strategy with a 12-month formation period

\begin{tabular}{lccccccccc}
\hline Mth & Ret & t-stat & P-val & C. Ret & Mth & Ret & t-stat & P-val & C. Ret \\
\hline 1 & -0.014 & -0.584 & 0.56 & -0.014 & 19 & 0.006 & 0.776 & 0.439 & 0.182 \\
2 & 0.038 & 2.242 & 0.027 & 0.024 & 20 & 0.011 & 1.388 & 0.168 & 0.193 \\
3 & 0.042 & 1.786 & 0.076 & 0.066 & 21 & 0.016 & 1.99 & 0.049 & 0.209 \\
4 & 0.037 & 1.533 & 0.128 & 0.103 & 22 & 0.012 & 1.622 & 0.107 & 0.221 \\
5 & 0.031 & 1.342 & 0.182 & 0.134 & 23 & 0.009 & 1.499 & 0.136 & 0.23 \\
6 & 0.032 & 1.372 & 0.172 & 0.166 & 24 & 0.002 & 0.279 & 0.781 & 0.232 \\
7 & 0.008 & 0.589 & 0.557 & 0.174 & 25 & 0.014 & 2.173 & 0.032 & 0.246 \\
8 & 0.015 & 0.886 & 0.377 & 0.189 & 26 & 0.002 & 0.27 & 0.788 & 0.247 \\
9 & 0.02 & 1.264 & 0.208 & 0.209 & 27 & 0.011 & 1.688 & 0.094 & 0.259 \\
10 & 0.002 & 0.218 & 0.828 & 0.212 & 28 & 0.004 & 0.659 & 0.511 & 0.263 \\
11 & -0.003 & -0.203 & 0.839 & 0.209 & 29 & 0.006 & 0.992 & 0.323 & 0.27 \\
12 & 0.004 & 0.281 & 0.78 & 0.212 & 30 & 0.008 & 1.161 & 0.248 & 0.278 \\
13 & 0.005 & 0.349 & 0.727 & 0.217 & 31 & -0.001 & -0.119 & 0.905 & 0.277 \\
14 & -0.007 & -0.855 & 0.394 & 0.21 & 32 & 0.002 & 0.296 & 0.768 & 0.279 \\
15 & -0.016 & -0.877 & 0.382 & 0.194 & 33 & 0.003 & 0.377 & 0.707 & 0.282 \\
16 & -0.002 & -0.273 & 0.786 & 0.192 & 34 & 0 & 0.039 & 0.969 & 0.282 \\
17 & -0.018 & -1.016 & 0.311 & 0.174 & 35 & 0.001 & 0.073 & 0.942 & 0.283 \\
18 & 0.002 & 0.302 & 0.763 & 0.176 & 36 & 0.003 & 0.427 & 0.67 & 0.286 \\
\hline
\end{tabular}

\subsubsection{Average size and beta of momentum portfolios}

Table 9 presents the post-ranking betas and average market capitalization for the ten momentum portfolios constructed under the two strategies: $12-6$ and 6-6, over the complete sample period. The post-ranking betas for different portfolios show that the beta decreased as we move from low performing portfolios to high performing portfolios. The portfolio comprising of stocks with the worst performance (loser portfolio) had the highest beta ( 0.77 for $12-6$ strategy and 0.73 for $6-6$ strategy) and the portfolio comprising of stocks with the best performance had the lowest beta (0.42 for 12-6 strategy and 0.52 for 6-6 strategy).

The average market capitalization was smallest for stocks in the loser portfolio in case of both strategies examined. As we move from low performing to high performing portfolios the average market capitalization first increases and then decreases again. Hence, the beta and size figures did not indicate any relationship between momentum returns and these factors.

Business Review: (2018) 13(1):21-36 
S. Tauseef, M. Nishat

Table 8: Event returns for momentum strategy with a 6-month formation period

\begin{tabular}{lccccccccc}
\hline Mth & Ret & t-stat & P-Val & C. Ret & Mth & Ret & t-stat & P- Val & C. Ret \\
\hline 1 & 0.012 & 0.693 & 0.49 & 0.012 & 19 & -0.001 & -0.069 & 0.945 & 0.148 \\
2 & 0.033 & 1.498 & 0.137 & 0.045 & 20 & -0.001 & -0.094 & 0.925 & 0.147 \\
3 & 0.027 & 1.208 & 0.229 & 0.072 & 21 & -0.015 & -0.887 & 0.377 & 0.132 \\
4 & 0.038 & 1.694 & 0.093 & 0.11 & 22 & 0.008 & 0.966 & 0.336 & 0.14 \\
5 & 0.015 & 0.556 & 0.579 & 0.124 & 23 & 0.008 & 1.02 & 0.309 & 0.148 \\
6 & 0.014 & 1.014 & 0.312 & 0.138 & 24 & 0.01 & 1.251 & 0.213 & 0.158 \\
7 & 0.02 & 0.906 & 0.367 & 0.158 & 25 & 0.006 & 0.751 & 0.454 & 0.164 \\
8 & -0.01 & -0.803 & 0.423 & 0.148 & 26 & 0.005 & 0.68 & 0.498 & 0.169 \\
9 & 0.003 & 0.135 & 0.893 & 0.15 & 27 & -0.002 & -0.238 & 0.812 & 0.168 \\
10 & 0.011 & 0.5 & 0.618 & 0.161 & 28 & -0.001 & -0.104 & 0.918 & 0.167 \\
11 & 0.019 & 1.034 & 0.303 & 0.18 & 29 & 0.002 & 0.294 & 0.769 & 0.169 \\
12 & -0.009 & -0.613 & 0.541 & 0.171 & 30 & 0 & -0.026 & 0.979 & 0.169 \\
13 & -0.009 & -0.434 & 0.665 & 0.162 & 31 & 0.004 & 0.584 & 0.56 & 0.173 \\
14 & -0.002 & -0.114 & 0.909 & 0.16 & 32 & 0.005 & 0.745 & 0.457 & 0.178 \\
15 & 0 & 0.002 & 0.998 & 0.16 & 33 & 0.002 & 0.298 & 0.766 & 0.18 \\
16 & -0.012 & -0.642 & 0.522 & 0.147 & 34 & 0.005 & 0.784 & 0.434 & 0.185 \\
17 & -0.001 & -0.051 & 0.96 & 0.147 & 35 & -0.038 & -1.567 & 0.119 & 0.147 \\
18 & 0.001 & 0.19 & 0.85 & 0.148 & 36 & 0.015 & 0.963 & 0.337 & 0.162 \\
\hline
\end{tabular}

Table 9: Post-ranking beta and average market capitalization of momentum portfolios

\begin{tabular}{lcccc}
\hline & \multicolumn{2}{c}{ 12-6 Strategy } & \multicolumn{2}{c}{ 6-6 Strategy } \\
\hline & Market Beta & Size & Market Beta & Size \\
\hline Portfolio 1 (Loser) & 0.77 & 2572.90 & 0.73 & 2281.85 \\
Portfolio 2 & 0.73 & 4748.73 & 0.71 & 5421.92 \\
Portfolio 3 & 0.66 & 4974.02 & 0.68 & 5548.79 \\
Portfolio 4 & 0.60 & 6214.47 & 0.61 & 6408.23 \\
Portfolio 5 & 0.60 & 6845.80 & 0.59 & 6833.03 \\
Portfolio 6 & 0.59 & 9258.76 & 0.52 & 7099.09 \\
Portfolio 7 & 0.58 & 7088.41 & 0.56 & 7192.17 \\
Portfolio 8 & 0.64 & 7882.46 & 0.55 & 7218.03 \\
Portfolio 9 & 0.58 & 6835.98 & 0.55 & 6670.00 \\
Portfolio 10 (Winner) & 0.42 & 5223.89 & 0.52 & 5270.04 \\
\hline
\end{tabular}

\subsubsection{Momentum returns within beta and size-based subsamples}

To check the relationship between momentum and the two factors of market risk and size, we examined the returns of the two momentum strategies within the subsamples based on beta and size factors. Sample stocks were sorted into three categories based on beta: high, medium, and low-beta portfolios. Momentum returns were calculated within each category.

Similarly for the size factor, sample stocks were sorted into three categories based on market capitalization: small, medium and big-size portfolios, and momentum returns were calculated within each category. If momentum returns are caused by systematic risk factors, then the returns would be lesser when they are computed for stocks within a single subsample. Table 10 presents momentum returns along with their t-statistics and p-values for the subsamples based on market risk (beta) and size (market capitalization). The momentum returns for the complete study sample are also presented for comparison.

For the subsamples based on beta, momentum returns were higher for low- 
Can investors benefit from momentum trading...

Table 10: Momentum returns for beta and size based portfolios

\begin{tabular}{lcccccc}
\hline & \multicolumn{3}{c}{ 12-6 Strategy } & \multicolumn{2}{c}{6 -6 Strategy } \\
\hline & Ret & t-Stat & P-Val & Ret & t-Stat & P-Val \\
\hline Low Beta Loser (LBL) & 0.032 & 5.865 & 0.000 & 0.038 & 5.795 & 0.000 \\
Low Beta Winner (LBW) & 0.055 & 4.522 & 0.000 & 0.051 & 4.599 & 0.000 \\
Low Beta Momentum (LBM) & 0.023 & 2.034 & 0.044 & 0.013 & 1.206 & 0.230 \\
High Beta Loser (HBL) & 0.039 & 4.868 & 0.000 & 0.033 & 4.296 & 0.000 \\
High Beta Winner (HBW) & 0.038 & 4.202 & 0.000 & 0.036 & 4.720 & 0.000 \\
High Beta Momentum (HBM) & 0.001 & 0.108 & 0.914 & 0.003 & 0.511 & 0.610 \\
HBM minus LBM & -0.022 & -1.598 & 0.112 & -0.011 & -0.911 & 0.364 \\
HBW minus LBL & 0.007 & 0.958 & 0.34 & -0.002 & -0.283 & 0.777 \\
Small Size Loser (SSL) & 0.044 & 5.465 & 0.000 & 0.046 & 5.488 & 0.000 \\
Small Size Winner (SSW) & 0.067 & 3.978 & 0.000 & 0.059 & 3.814 & 0.000 \\
Small Size Momentum (SSM) & 0.023 & 1.407 & 0.023 & 0.013 & 0.858 & 0.392 \\
Big Size Loser (BSL) & 0.032 & 4.298 & 0.000 & 0.028 & 4.468 & 0.000 \\
Big Size Winner (BSW) & 0.033 & 4.811 & 0.000 & 0.037 & 3.965 & 0.000 \\
Big Size Momentum (BSM) & 0.001 & 0.150 & 0.881 & 0.009 & 1.29 & 0.199 \\
SSM minus BSM & 0.023 & 1.377 & 0.170 & 0.004 & 0.245 & 0.807 \\
SSW minus BSL & 0.035 & 2.125 & 0.035 & 0.031 & 1.977 & 0.050 \\
Traditional Momentum & 0.018 & 1.071 & 0.286 & 0.009 & 0.699 & 0.486 \\
\hline
\end{tabular}

beta stocks and lesser for high-beta stocks and for the subsamples based on size, momentum returns were higher for small-size stocks and lower for big-size stocks. However, the difference between momentum returns for these subsamples was not significant. Thus, the figures in table 10 also suggest that momentum returns were not caused by the factors of size and beta, a finding which is consistent with many studies in literature (Jegadeesh and Titman 1993; Sehgal and Jain 2011; Hanauer and Linhart 2015).

However, an interesting finding is that momentum returns could be enhanced if the size factor along with momentum was considered in stock selection. This is evident by the significant momentum return of 3.50 percent per month (which is twice as much as the return which a traditional momentum strategy of the entire sample earned) which could have been earned by buying the small-size-winner (SSW portfolio) and selling the big-size-loser (BSL portfolio).

\section{Conclusion}

Momentum patterns in emerging equity markets have not been adequately explained in existing literature. This study examined momentum profits and their determinants using data from the Pakistan Stock Exchange. The results revealed positive but insignificant momentum returns for Pakistani stocks over the period from 2001 to 2015. However, for the sub-period, from 2001 to 2007, when there was an autocratic government in Pakistan and the economy experienced high growth, low inflation and better governance, few momentum strategies earned significant returns. These results suggest that momentum returns for Pakistani stocks are time-specific.

We analyzed momentum returns up to 36 months and positive returns were observed for most months following the holding period suggesting that mo-

Business Review: (2018) 13(1):21-36 
mentum returns were not caused by the temporary over or under reaction of investors in the market. Moreover, post-ranking beta and average capitalization of momentum portfolios and the traditional analysis of momentum profits within beta and size sub-samples showed that momentum profits were unrelated to beta and size factors. However, an interesting byproduct of our analysis is the finding that significant momentum returns could have been earned by buying the small-size-winner stocks and selling the big-size-loser stocks.

The findings of this study highlight that investors in Pakistani stocks should not follow momentum-based investment styles at all times because, over time, stock returns show a mix of momentum and reversal patterns. Investors should take into account, political and economic factors before using the momentum strategies. Moreover, investors can enhance the returns by combining the size factor with momentum.

Our study was based on the sample of surviving firms for the entire sample period and this might have biased our results. Accordingly, we pinpoint this area as one worthy of further research. Future research can be conducted on the risk factors such as book-to-market ratio and the trading volume. Also, momentum returns for Pakistani stocks can be compared with returns earned by stocks of other countries which are part of the MSCI emerging market index.

\section{References}

Barberis N, Shleifer A, Vishny R (1998) A model of investor sentiment. Journal of Financial Economics 49(3):307-343

Chan LK, Jegadeesh N, Lakonishok J (1996) Momentum strategies. The Journal of Finance 51(5):1681-1713

Chordia T, Shivakumar L (2002) Momentum, business cycle, and time-varying expected returns. The Journal of Finance 57(2):985-1019

Conrad J, Kaul G (1998) An anatomy of trading strategies. The Review of Financial Studies 11(3):489-519

Cooper MJ, Gutierrez Jr RC, Hameed A (2004) Market states and momentum. The Journal of Finance 59(3):1345-1365

Daniel K, Hirshleifer D, Subrahmanyam A (1998) Investor psychology and security market under-and overreactions. the Journal of Finance 53(6):1839-1885

Fama EF, French KR (1992) The cross-section of expected stock returns. The Journal of Finance 47(2):427-465

Fernandes JLB, Ornelas JRH (2008) Momentum and reversal puzzle in emerging markets. ICFAI Journal of Behavioral Finance 5(3):54-71

Gutierrez Jr RC, Kelley EK (2008) The long-lasting momentum in weekly returns. The Journal of Finance 63(1):415-447

Habib-Ur-Rahman, Mohsin HM (2012) Momentum effect: empirical evidence from karachi stock exchange. The Pakistan Development Review 51(4):449-461

Haider A, ud Din M, Ghani E (2011) Consequences of political instability, governance and bureaucratic corruption on inflation and growth: The case of pakistan. The Pakistan Development Review 50(4):773-807

Hanauer MX, Linhart M (2015) Size, value, and momentum in emerging market stock returns: integrated or segmented pricing? Asia-Pacific Journal of Financial Studies 44(2):175-214

Jegadeesh N, Titman S (1993) Returns to buying winners and selling losers: Implications for stock market efficiency. The Journal of Finance 48(1):65-91

Macha E (2013) Momentum and industry-dependence: The case of shanghai stock exchange market. International Journal of Management Sciences and Business Research 
Misra AK, Mohapatra S (2014) Evidence and sources of momentum profits. a study on indian stock market. Economics, Management and Financial Markets 9(3):86

Moskowitz TJ, Grinblatt M (1999) Do industries explain momentum? The Journal of Finance 54(4):1249-1290

Muga L, Santamaria R (2007) The momentum effect in latin american emerging markets. Emerging Markets Finance and Trade 43(4):24-45

Rouwenhorst KG (1998) International momentum strategies. The Journal of Finance 53(1):267-284

Rouwenhorst KG (1999) Local return factors and turnover in emerging stock markets. The Journal of Finance 54(4):1439-1464

Sehgal S, Jain S (2011) Short-term momentum patterns in stock and sectoral returns: evidence from india. Journal of Advances in Management research 8(1):99-122

Shah SHA, Shah A (2015) Can momentum portfolios earn more in the karachi stock exchange? The Pakistan Business Review

Business Review: (2018) 13(1):21-36 
https://ir.iba.edu.pk/businessreview/vol13/iss1/2

DOI: https://doi.org/10.54784/1990-6587.1035

S. Tauseef, M. Nishat

\section{Appendix}

Table A1: Momentum strategies with different formation and holding periods

\begin{tabular}{|c|c|c|}
\hline $\begin{array}{l}\text { Momentum } \\
\text { strategy }\end{array}$ & $\begin{array}{l}\text { Selection } \\
\text { period }\end{array}$ & $\begin{array}{l}\text { Holding } \\
\text { period }\end{array}$ \\
\hline $3-3$ & 3 & 3 \\
\hline $3-6$ & 3 & 6 \\
\hline $3-9$ & 3 & 9 \\
\hline $3-12$ & 3 & 12 \\
\hline $3-24$ & 3 & 24 \\
\hline $6-3$ & 6 & 3 \\
\hline $6-6$ & 6 & 6 \\
\hline $6-9$ & 6 & 9 \\
\hline $6-12$ & 6 & 12 \\
\hline $6-24$ & 6 & 24 \\
\hline $9-3$ & 9 & 3 \\
\hline $9-6$ & 9 & 6 \\
\hline $9-9$ & 9 & 9 \\
\hline $9-12$ & 9 & 12 \\
\hline $9-24$ & 9 & 24 \\
\hline $12-3$ & 12 & 3 \\
\hline $12-6$ & 12 & 6 \\
\hline $12-9$ & 12 & 9 \\
\hline $12-12$ & 12 & 12 \\
\hline $12-24$ & 12 & 24 \\
\hline $24-3$ & 24 & 3 \\
\hline $24-6$ & 24 & 6 \\
\hline $24-9$ & 24 & 9 \\
\hline $24-12$ & 24 & 12 \\
\hline $24-24$ & 24 & 24 \\
\hline
\end{tabular}

